\title{
Critical Chloride Corrosion Threshold of Galvanized Reinforcing Bars
}

\author{
by David Darwin, JoAnn Browning, Matthew O’Reilly, Lihua Xing, and Jianxin Ji
}

\begin{abstract}
The chloride content required for corrosion initiation of galvanized reinforcing bars is determined. The bars conform to ASTM A767, except that no chromate treatment was applied to allow the degree of hydrogen evolution for untreated bars to be evaluated. Test results, along with results for conventional (ASTM A615), low carbon chromium (ASTM A1035, MMFX), and 316LN stainless steel reinforcement are compared with chloride surveys of bridge decks to obtain an average time to corrosion initiation.

The average critical chloride corrosion threshold of galvanized reinforcement is greater than the threshold for conventional steel and lower than the threshold for ASTM A1035 and 316LN steel. Hydrogen gas evolution did not increase the porosity of the concrete in the non-chromate treated bars relative to that observed for conventional reinforcement. The average time to corrosion initiation at crack locations in bridge decks for galvanized steel is 4.8 years, compared with 2.3 years for conventional steel, and 15 years for ASTM A1035 steel. 316LN stainless steel will not corrode.
\end{abstract}

Keywords: bridge decks; corrosion; galvanized reinforcement; low carbon chromium steel; stainless steel, zinc.

\section{INTRODUCTION}

Metallic coatings of different types have been used for many years to protect steel from corrosion. Principal among the metals has been zinc, applied as a molten coating. The process results in the formation of an outer layer of pure zinc that is underlaid by several zinc-iron alloy layers. Zinc provides protection in two ways. It acts as a barrier that prevents access of oxygen and moisture to the protected material, and it acts as a sacrificial anode that corrodes in preference to the protected metal. In air, zinc achieves significant protection itself due to the formation of a hydrated oxide, $\mathrm{Zn}(\mathrm{OH})_{2}$, which in turn combines with carbon dioxide in the atmosphere to form a protective zinc carbonate layer, $\mathrm{ZnCO}_{3}$, that prevents further corrosion (Jones 1996).

In concrete, the behavior of zinc is somewhat different. Zinc reacts with hydroxyl ions in plastic concrete and concrete pore solution to form zinc oxide and hydrogen gas. Zinc oxide reacts with calcium ions to form calcium hydroxyzincate. At a $\mathrm{pH}$ below 13.3, calcium hydroxyzincate forms a stable coating that passivates the zinc. Above a $\mathrm{pH}$ of 13.3, the corrosion products form large crystals that do not provide corrosion protection (Andrade and Macias 1988; Bentur et. al. 1997). A key aspect of providing corrosion protection is the retention of the external layer of pure zinc. Once this layer is lost, the zinc required to form calcium hydroxyzincate is removed and the underlying zinc-iron alloy layers are destroyed (Andrade and Macias 1988). $\mathrm{pH}$ values above 13.3 are typical for concrete (Struble 1988).

Hot-dipped zinc-coated reinforcing steel is specified under ASTM A767. Because zinc is an amphoteric metal, that is, it corrodes in alkaline as well as acid environments,
ASTM A767 requires galvanized bars to be dipped in a chromate bath after coating to passivate the zinc surface and prevent the zinc from reacting with hydroxyl ions in fresh concrete (Virmani and Clemeña 1998).

Over the years, the ability of galvanized bars to provide corrosion resistance has not been uniformly positive. There have been cases in which galvanized bars have performed in a superior manner (McCrum and Arnold 1993) and other cases in which they have performed poorly (Manning et al. 1982; Pianca and Schell 2005). The use of chromate treatment also has negative implications because the hexavalent chromate salts that are used to passivate the zinc can cause health problems and are considered to be "potential occupational carcinogens" (NIOSH 2005).

Conventional reinforcing steel does not need corrosion protection for most applications. The reason is that the alkaline environment within concrete results in the deposition of a passive ferric oxyhydroxide layer on the surface of the bar. The layer limits access of oxygen and moisture to the steel while reducing the solubility of iron. This protection, however, can be lost. For example, this will occur if the $\mathrm{pH}$ of the concrete drops, such as due to carbonation from the chemical combination of carbon dioxide in the air with alkalis in hydrated cement. Carbonation is generally not a problem unless the concrete cover is low because the carbonation process penetrates the concrete at progressively slower rates with increasing depth. Corrosion protection is also lost when reinforced concrete is subjected to chlorides, usually in the form of deicing chemicals or sea water. The chlorides penetrate the passive layer on the steel surface and cause active corrosion. Because of the wide-spread use of sodium and calcium chloride as deicing chemicals, chloride-induced corrosion represents a major durability problem for concrete bridges, especially for reinforced concrete bridge decks.

There are two aspects to providing corrosion protection for reinforcing steel: raising the chloride content in the concrete that corresponds to the loss of the passivity and slowing the rate of corrosion once it has begun. The purpose of this study is to evaluate the first of these aspects for galvanized reinforcing steel, that is, the effect of the zinc coating on the chloride concentration required to initiate corrosion. This chloride content is known as the critical chloride corrosion threshold. The critical chloride corrosion threshold of galvanized bars is compared with the corresponding thresholds for conventional (ASTM A615) reinforcement, ASTM A1035 (MMFX)

ACI Materials Journal, V. 106, No. 2, March-April 2009.

MS No. M-2008-174 received May 30, 2008, and reviewed under Institute publication policies. Copyright $\odot$ 2009, American Concrete Institute. All rights reserved, including the making of copies unless permission is obtained from the copyright proprietors. Pertinent discussion including authors' closure, if any, will be published in the January-February 2010 ACI Materials Journal if the discussion, will be pece 
ACI Past President David Darwin, FACI, is the Deane E. Ackers Distinguished Professor of Civil, Environmental and Architectural Engineering and Director of the Structural Engineering and Materials Laboratory at the University of Kansas, Lawrence, KS. He is a member of ACI Committees 130, Sustainability of Concrete; 222, Corrosion of Metals in Concrete; 224, Cracking; 318-B, Reinforcement and Development (Structural Concrete Building Code); 408, Bond and Development of Reinforcement; 446, Fracture Mechanics; and Joint ACI-ASCE Committee 445, Shear and Torsion.

ACI member JoAnn Browning is an Associate Professor of civil, environmental, and architectural engineering at the University of Kansas. She is Chair of ACI Committee 314, Simplified Design of Concrete Buildings, and is a member of ACI Committees 318-D, Flexure and Axial Loads: Beams, Slabs, and Columns (Structural Concrete Building Code); 341, Earthquake-Resistant Concrete Bridges; 374, Performance-Based Seismic Design of Concrete Buildings; and 408, Bond and Development of Reinforcement.

ACI member Matthew O'Reilly is a Graduate Student pursuing his PhD at the University of Kansas. He received his BS in mechanical engineering from the University of Rochester, Rochester, NY, and his MS in civil engineering from the University of Kansas.

ACI member Lihua Xing is a Structural Engineer with Archer Daniels Midland Company in Decatur, IL, and is completing work on her PhD at the University of Kansas. She received a BS in structural engineering from Lanzhou Jiaotong University, Gansu, China, and her MS in mathematics from Marquette University, Milwaukee, WI.

ACI member Jianxin Ji is a Structural Engineer in Lawrence, KS. He received his BS and MS in building materials from Chongqing University, Chongqing, China, and his $P h D$ in civil engineering from the University of Kansas.

reinforcement, and 316LN stainless steel, with the latter serving as cladding for stainless steel clad reinforcement. The galvanized bars evaluated in this study were not pretreated with hexavalent chromium salts to determine if there is any visible evidence of the formation of hydrogen at the surface of the bars. The full details of the study are presented by Darwin et al. (2007b).

\section{RESEARCH SIGNIFICANCE}

Because of the mixed performance of galvanized reinforcement under severe corrosion conditions, a number of questions exist about the usefulness of zinc coatings as a protective measure for reinforcing steel-questions that can be best answered through laboratory tests. The critical chloride corrosion threshold establishes the degree of chloride exposure at which corrosion begins. The value of the chloride threshold obtained in this study can be used to predict the life expectancy of concrete structures reinforced with galvanized steel when subjected to deicing chemicals and seawater and will improve the ability of the engineers to select effective corrosion protection systems for reinforcing steel.

\section{EXPERIMENTAL WORK}

This study involves the determination of the critical chloride corrosion threshold of galvanized steel reinforcing bars. Class I galvanized No. 5 (No. 16) bars that meet the requirements of ASTM A767 but lack chromate treatment are used to fabricate 12 beam specimens (Fig. 1). The specimens are autopsied following the tests to look for evidence of increased porosity in the concrete around the nonchromated bars, possibly caused by excessive hydrogen evolution during initial curing, and the presence of corrosion products on the bars.

\section{Summary of critical chloride threshold test}

The chloride threshold test used in this study is similar in a number of ways to a new test being considered by ASTM Subcommittee G01.14 that is based on ASTM G109, but involves exposure conditions that increase the rate of chloride penetration and, thus, shorten the duration of the test. The test includes a chemical analysis to determine the chloride content in concrete beam specimens adjacent to reinforcing steel when corrosion starts. The beam specimens are 7 in. (178 mm) deep, 6 in. (153 mm) wide, and 12 in. (305 mm) long, as shown in Fig. 1. Each specimen contains three No. 5 (No. 16) reinforcing bars, oriented in the 12 in. (305 $\mathrm{mm})$ direction, one with $1 \mathrm{in}$. (25.4 $\mathrm{mm})$ top cover, and two with 1 in. $(25.4 \mathrm{~mm})$ bottom cover. The ends of the bars are flush with the sides of the specimen. The top and bottom bars are electrically connected across a $10 \mathrm{ohm}$ resistor, and the sides of the specimen and bar ends are covered with epoxy after the electrical connection is completed. The cut ends of the bars did not corrode, and the bar surface near the ends did not exhibit corrosion that was distinct from that observed over the rest of the bar. The specimens are subjected to an exposure regime that consists of 4 days ponding with a $15 \%$ sodium chloride solution [solution depth $=3 / 8 \mathrm{in}$. $(9.5 \mathrm{~mm})$ ] at room temperature followed by 3 days drying (after removal of the solution) at $100{ }^{\circ} \mathrm{F}\left(38^{\circ} \mathrm{C}\right)$. This 7 -day regime is repeated for 12 weeks, and then the specimens are ponded for 12 weeks at room temperature. During the 12-week ponding period, the depth of the solution is monitored on a weekly basis and maintained, as needed, by adding deionized water. The combined 24-week cycle is repeated until corrosion is initiated, as represented by a measured corrosion rate above $0.3 \mu \mathrm{m} / \mathrm{year}$ and a sharp drop in the corrosion potential. The corrosion rate of $0.3 \mu \mathrm{m} /$ year is based on the analysis of a large number of tests that indicate that once a value of $0.3 \mu \mathrm{m} / \mathrm{year}$ is attained, subsequent corrosion proceeds at a much higher rate (Ji et al. 2005). Readings are taken once per week during the test period. Exposure to the sodium chloride solution is terminated upon initiation of corrosion, and 20 samples, 10 from each side of the specimen, are obtained by drilling at the level of the upper reinforcing bar, as shown in Fig. 1.

\section{Concrete}

The concrete had a water-cement ratio $(w / c)$ of 0.45 and an air content of $6 \%$. The concrete mixture proportions are shown in Table 1, and the properties of the materials are as follows: Type I/II portland cement; coarse aggregate: crushed limestone with maximum size $=0.75$ in.$(19 \mathrm{~mm})$, bulk specific gravity $(\mathrm{SSD})=2.58$, absorption $($ dry $)=2.27 \%$, unit weight $=95.9 \mathrm{lb} / \mathrm{ft}^{3}\left(1536 \mathrm{~kg} / \mathrm{m}^{3}\right)$; fine aggregate: Kansas River sand with bulk specific gravity $(\mathrm{SSD})=2.62$, absorption $($ dry $)=0.78 \%$, fineness modulus $=3.18$.

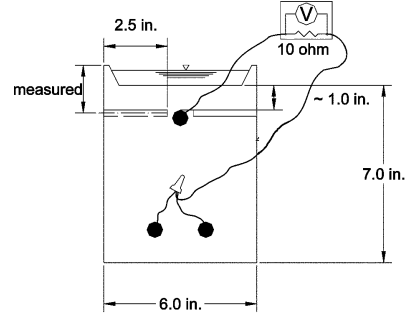

(a)

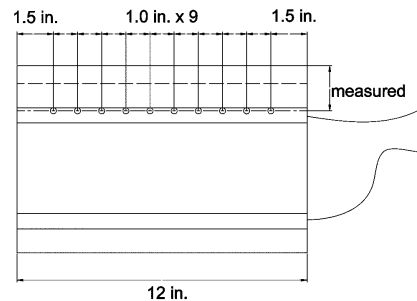

(b)
Fig. 1-Beam specimen: (a) end view; and (b) side view showing sampling locations.

Table 1-Concrete mixture proportions (SSD basis)

\begin{tabular}{c|c|c|c|c}
\hline $\begin{array}{c}\text { Cement, } \\
\mathrm{lb} / \mathrm{yd}^{3} \\
\left(\mathrm{~kg} / \mathrm{m}^{3}\right)\end{array}$ & $\begin{array}{c}\text { Water, } \\
\mathrm{lb} / \mathrm{yd}^{3} \\
\left(\mathrm{~kg} / \mathrm{m}^{3}\right)\end{array}$ & $\begin{array}{c}\text { Fine } \\
\text { aggregate, } \\
\mathrm{lb} / \mathrm{yd}^{3}\left(\mathrm{~kg} / \mathrm{m}^{3}\right)\end{array}$ & $\begin{array}{c}\text { Coarse } \\
\text { aggregate, } \\
\mathrm{lb} / \mathrm{yd}^{3}\left(\mathrm{~kg} / \mathrm{m}^{3}\right)\end{array}$ & $\begin{array}{c}\text { Vinsol resin, } \\
\mathrm{gal}^{3} / \mathrm{yd}^{3} \\
\left(\mathrm{~mL} / \mathrm{m}^{3}\right)\end{array}$ \\
\hline $598(355)$ & $270(160)$ & $1436(852)$ & $1473(874)$ & $0.024(90)$ \\
\hline
\end{tabular}




\section{Specimen fabrication}

The beam specimens are fabricated in an inverted position. The concrete is placed in two layers. Each layer is consolidated for 30 seconds on a vibrating table with an amplitude of $0.006 \mathrm{in} .(0.15 \mathrm{~mm})$ and a frequency of $60 \mathrm{~Hz}$. The specimens are wet cured for 3 days ( 1 day in the form and 2 days in a plastic bag with deionized water) and then air cured until the test begins at 28 days. The top surface of the concrete is sanded lightly and all four sides are coated with two layers of epoxy prior to initiation of the tests.

\section{Corrosion rate}

The corrosion rates for zinc and iron, in $\mu \mathrm{m} / \mathrm{year}$, are obtained from the measured voltage drop across the $10 \mathrm{ohm}$ resistor using Faraday's equation (Jones 1996) as follows:

$$
\begin{aligned}
& \text { Corrosion rate for zinc }=14.96 i=14.96 \frac{V}{R A} \\
& \text { Corrosion rate for iron }=11.59 i=11.59 \frac{\mathrm{V}}{R A}
\end{aligned}
$$

where $i$ is the current density, $\mu \mathrm{A} / \mathrm{cm}^{2} ; V$ is the voltage drop across the resistor, $\mathrm{mV} ; R$ is the resistance of the resistor, $\mathrm{k} \Omega$ $(R=10 \Omega=0.01 \mathrm{k} \Omega)$; and $A$ is the area of the anode bar, $\mathrm{cm}^{2}$ (Note: It is usual in corrosion calculations to express area in $\mathrm{cm}^{2}$ rather than in. ${ }^{2}$ or $\mathrm{mm}^{2}$.) The anode area $A$ for a beam specimen is $152 \mathrm{~cm}^{2}$.

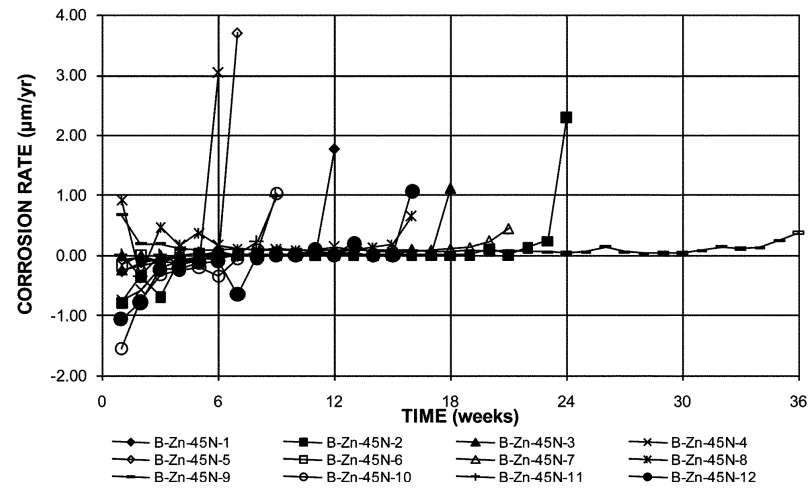

Fig. 2-Corrosion rates for beam specimens containing galvanized reinforcing steel.

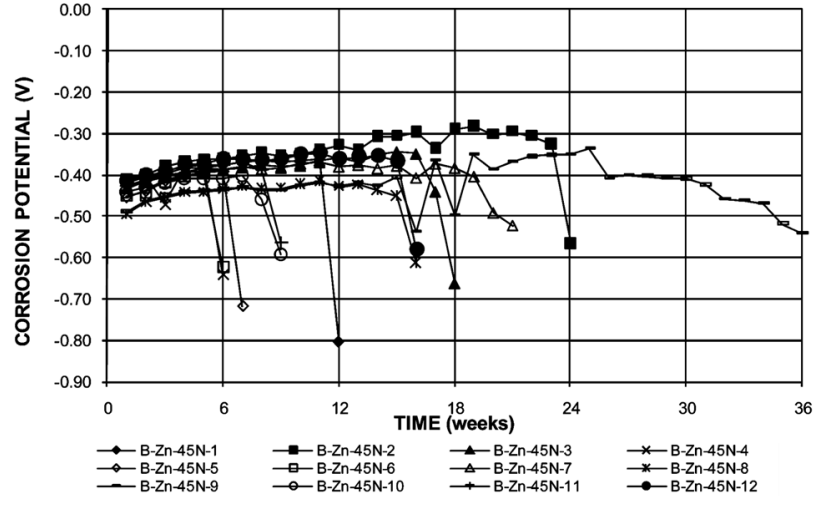

Fig. 3-Corrosion potential versus CSE for top bars in beam specimens containing galvanized reinforcing steel.

\section{Sampling and testing for chloride ion concentration in concrete}

Pulverized concrete samples are obtained by drilling 0.25 in. $(6.4 \mathrm{~mm})$ diameter holes into the side of the specimens using a rotary impact drill. For each sample, holes are centered so that the top of the holes and the top surface of the bar are in the same plane. Because the concrete cover for each bar is not exactly 1 in. $(25.4 \mathrm{~mm})$, the actual cover is measured to determine the depth at which the sample is taken.

Prior to sampling, the concrete surface is cleaned three times, first using soap and water, then using tap water, and finally deionized water, and dried with paper towels. A hole is drilled to a depth of $0.5 \mathrm{in}$. $(12.7 \mathrm{~mm})$, the powdered concrete discarded, and the surface and hole cleaned using a vacuum. The concrete is then sampled to a depth of $2.5 \mathrm{in}$. (64 mm). Each hole produces a sample yield of approximately $4 \mathrm{~g}$.

The water-soluble chloride content of concrete is determined using Procedure A (the potentiometric titration test) in AASHTO T 260-97. The chloride content, in percent of weight (mass) of concrete, is converted to $\mathrm{lb} / \mathrm{yd}^{3}\left(\mathrm{~kg} / \mathrm{m}^{3}\right)$ of concrete by multiplying by the unit weight of the concrete.

After the powdered samples are obtained, the specimens are autopsied. The bars are observed for corrosion products, and the concrete adjacent to the bars is inspected for evidence of the formation of hydrogen bubbles before the concrete had set.

\section{Test program}

The test program consisted of 12 beam specimens containing galvanized reinforcement, cast in two groups of six specimens each. The results from these tests are compared with results obtained by $\mathrm{Ji}$ et al. (2005) for conventional (ASTM A615) and ASTM A1035 reinforcement and by Darwin et al. (2007a) for 316LN stainless steel clad bars.

\section{TEST RESULTS AND EVALUATION}

The corrosion rates and corrosion potentials of the 12 beam specimens containing galvanized reinforcing steel are shown, respectively, in Fig. 2 and 3. The specimens were exposed to the salt solutions until the corrosion rate reached $0.3 \mu \mathrm{m} /$ year or when a sharp change in corrosion potential of the top mat of reinforcing steel was observed, with the former serving as the primary guide. The figures show that the corrosion rates were variable during the first 4 to 6 weeks of the tests, with the corrosion potentials of both the top (shown in Fig. 3) and bottom (not shown) mats stabilizing near $-0.40 \mathrm{~V}$ with respect to a copper-copper sulfate electrode (CSE). The early variations in corrosion rate, including apparently negative values, result from the amphoteric nature of zinc. The corrosion rate is based on the macrocell current between the top and bottom mats of steel, and early in the test, before significant quantities of chloride have reached the top steel, the current is actually more likely to indicate "negative corrosion" because the bottom mat contains two bars, compared to the single bar in the top mat.

Upon the initiation of corrosion, the corrosion rate turns sharply positive (usually from one week to the next) and the corrosion potential of the top mat changes sharply to more negative values. This was true, except for Specimens 2 and 9. The corrosion rate of Specimen 2 increased from zero to a value above $0.3 \mu \mathrm{m} /$ year over a 2 -week period, whereas the corrosion rate for Specimen 9 increased gradually between weeks 24 and 36. Following corrosion initiation, the tests 
were stopped, samples were taken for chloride analysis, and the specimens were autopsied.

\section{Corrosion threshold}

The results of the chloride analyses for the galvanized bars are presented in Table 2. The table includes the times-toinitiation, corrosion rates, corrosion potentials, and individual and average critical chloride contents on a water-soluble basis. To limit the effect of outliers, chloride contents that are more than two standard deviations away from the mean are removed from consideration and the remaining values are again averaged. Twelve data points, or $5 \%$ of the 240 chloride values, were removed for the galvanized bars. They are identified by a " $\neq$ " in Table 2 .

The bars had times-to-initiation ranging from 6 to 36 weeks, with an average corrosion rate of $1.37 \mu \mathrm{m} /$ year and an average corrosion potential of $-0.619 \mathrm{~V}$ with respect to a copper-copper sulfate electrode at corrosion initiation. After the removal of outliers, the average chloride threshold for the specimens is $2.57 \mathrm{lb} / \mathrm{yd}^{3}\left(1.52 \mathrm{~kg} / \mathrm{m}^{3}\right)$. The individual chloride contents range from 0.22 to $7.82 \mathrm{lb} / \mathrm{yd}^{3}\left(0.13\right.$ to $\left.4.64 \mathrm{~kg} / \mathrm{m}^{3}\right)$, and the average values for the individual specimens range from 1.00 to $4.93 \mathrm{lb} / \mathrm{yd}^{3}\left(0.59\right.$ to $\left.2.93 \mathrm{~kg} / \mathrm{m}^{3}\right)$. The coefficients of variation (COV) for individual bars range from 0.31 to 0.97 , and the $\mathrm{COV}$ for the average specimen threshold values is 0.62 .

\section{Comparisons with conventional, ASTM A1035, and 316LN clad reinforcement}

The critical chloride corrosion thresholds for conventional (ASTM A615) and low carbon chromium (ASTM A1035) reinforcement were measured by $\mathrm{Ji}$ et al. (2005) and are presented, respectively, in Tables 3 and 4. The threshold values were obtained using beam specimens, as used for galvanized bars in this study, and modified southern exposure (MSE) specimens, which are twice the width of the beam specimens and contain two top bars with four bottom bars; the top bars are monitored individually and 10 samples are taken from each side of the specimens once corrosion has initiated in the bar. The MSE specimens are subjected to the same exposure conditions as the beam specimens.

Because twice as many samples are taken from the beam specimens, they receive twice the weight assigned the MSE specimens when calculating the average chloride corrosion threshold. Five chloride values, or $3.5 \%$ of the chloride values, were removed from consideration for conventional steel and three chloride values, or $2.1 \%$ of the chloride values, were removed for ASTM A1035 steel because the values were more than two standard deviations away from the mean.

The 316LN clad bars did not corrode during the tests (Darwin et al. 2007a), and the chloride content at 96 weeks is used as the lower bound of the critical chloride corrosion threshold. Chloride samples were taken from 12 southern

Table 2-Galvanized steel critical chloride threshold

\begin{tabular}{|c|c|c|c|c|c|c|c|c|c|c|c|c|c|c|c|c|c|}
\hline \multirow[b]{2}{*}{ Specimens ${ }^{*}$} & \multirow[b]{2}{*}{$\operatorname{Side}^{\dagger}$} & \multirow{2}{*}{$\begin{array}{l}\text { Age, } \\
\text { weeks }\end{array}$} & \multirow{2}{*}{$\begin{array}{l}\text { Rate, } \\
\mu \mathrm{m} / \text { year }\end{array}$} & \multirow{2}{*}{$\begin{array}{c}\text { Potential, } \\
\text { V }\end{array}$} & \multicolumn{10}{|c|}{ Water soluble $\mathrm{Cl}^{-}, \mathrm{lb} / \mathrm{yd}^{3}$} & \multirow{2}{*}{$\begin{array}{c}\text { Average, } \\
\mathrm{lb} / \mathrm{yd}^{3}\end{array}$} & \multirow{2}{*}{$\begin{array}{l}\text { Standard } \\
\text { deviation }\end{array}$} & \multirow{2}{*}{$\begin{array}{l}\text { Coefficient } \\
\text { of variation }\end{array}$} \\
\hline & & & & & 1 & 2 & 3 & 4 & 5 & 6 & 7 & 8 & 9 & 10 & & & \\
\hline \multirow{2}{*}{ Z-B-1 } & 1 & \multirow{2}{*}{12} & \multirow{2}{*}{1.77} & \multirow{2}{*}{-0.805} & 2.90 & 5.68 & 3.00 & 7.11 & 5.19 & 3.91 & 5.17 & 5.99 & 3.03 & 2.52 & \multirow{2}{*}{4.93} & \multirow{2}{*}{1.50} & \multirow{2}{*}{0.31} \\
\hline & 2 & & & & 5.11 & 7.70 & 4.29 & $9.72^{\ddagger}$ & 4.67 & 5.11 & 7.57 & 5.43 & 4.23 & 4.98 & & & \\
\hline \multirow{2}{*}{ Z-B-2 } & 1 & \multirow{2}{*}{24} & \multirow{2}{*}{2.30} & \multirow{2}{*}{-0.566} & 4.79 & 3.22 & 2.21 & 2.46 & 4.23 & 3.85 & 3.15 & 1.51 & 4.29 & 3.22 & \multirow{2}{*}{3.44} & \multirow{2}{*}{1.32} & \multirow{2}{*}{0.38} \\
\hline & 2 & & & & 4.92 & 4.48 & 5.87 & 4.35 & 4.86 & 1.26 & 3.72 & 1.77 & 3.28 & 1.45 & & & \\
\hline \multirow{2}{*}{ Z-B-3 } & 1 & \multirow{2}{*}{18} & \multirow{2}{*}{1.12} & \multirow{2}{*}{-0.664} & 7.38 & $8.64^{\ddagger}$ & 6.56 & 2.33 & 2.27 & 1.70 & 1.83 & 2.33 & 2.69 & 1.44 & 308 & 27 & 57 \\
\hline & 2 & & & & 1.01 & 6.88 & 6.15 & 7.44 & 5.36 & 4.61 & 1.89 & 4.35 & $8.20^{\ddagger}$ & 5.49 & 3.90 & 2.21 & 0.01 \\
\hline 7-B-4 & 1 & 6 & 304 & -0642 & 0.32 & 0.95 & 0.38 & 1.04 & 0.88 & 1.39 & 1.77 & 1.70 & 0.69 & 1.39 & 107 & 057 & 053 \\
\hline$Z-D-4$ & 2 & 0 & 3.04 & .042 & 0.57 & 0.85 & 1.51 & 0.45 & 2.33 & 0.57 & 1.07 & 0.69 & 2.02 & 0.82 & 1.07 & 0.57 & 0.53 \\
\hline $7-B-5$ & 1 & 7 & 360 & 07 & 2.52 & 4.10 & 0.57 & 2.27 & 2.46 & 1.26 & 1.70 & 0.66 & 2.71 & 2.09 & 225 & 163 & 073 \\
\hline $2-10-5$ & 2 & 1 & 3.09 & -0.11 & 7.19 & 4.89 & 1.26 & 1.14 & 1.89 & 1.39 & 2.46 & 0.38 & 3.09 & 1.01 & 2.25 & 1.63 & 0.13 \\
\hline Z-B-6 & 1 & 6 & 0.00 & 62 & 1.07 & 1.20 & 1.39 & 0.63 & 1.01 & 0.38 & 0.22 & 0.41 & 2.33 & 0.38 & 13 & 079 & 77 \\
\hline & 2 & & & & 1.39 & 0.44 & 0.25 & 0.50 & 0.57 & 1.48 & 0.82 & 1.07 & 3.47 & 1.58 & & & \\
\hline & 1 & 21 & 044 & & 3.15 & 7.82 & 1.45 & 2.52 & 2.97 & $8.77^{\ddagger}$ & 4.73 & 2.78 & 1.77 & 1.70 & & & \\
\hline$Z-\mathrm{B}-1$ & 2 & 21 & 0.44 & $5 \angle 4$ & 1.07 & 1.45 & 2.71 & 3.85 & 3.09 & 2.78 & 6.56 & 1.77 & 1.89 & 6.94 & 1 & 1.90 & 0.01 \\
\hline 7-B-8 & 1 & 16 & 065 & -0.61 & 1.07 & 3.85 & 0.82 & 1.01 & 1.20 & 0.88 & 3.00 & 4.67 & 2.08 & 2.21 & 388 & 226 & 058 \\
\hline$Z-B-8$ & 2 & 10 & 0.03 & -0.013 & 4.48 & 4.86 & 4.98 & 7.25 & 5.24 & 7.51 & 4.98 & 7.38 & 6.18 & 3.91 & 3.88 & 2.20 & 0.58 \\
\hline $7 \mathrm{P} 0$ & 1 & 36 & 037 & 0541 & 5.55 & 1.77 & 2.71 & 3.53 & 2.02 & 1.58 & 2.40 & 2.84 & 1.58 & 1.64 & 362 & 27 & 0.63 \\
\hline $2-D-3$ & 2 & 50 & 0.51 & -0.041 & 6.81 & 7.44 & $10.9^{\ddagger}$ & $7.95^{\ddagger}$ & $8.39^{\ddagger}$ & $9.53^{\ddagger}$ & $9.72^{\ddagger}$ & $9.40^{*}$ & $11.3^{\ddagger}$ & 7.13 & 3.02 & 2.21 & 0.05 \\
\hline 7-B-10 & 1 & 9 & 102 & $=592$ & 1.26 & 0.50 & 0.54 & 0.32 & 0.35 & 3.34 & 1.83 & 1.07 & 0.63 & 0.44 & 100 & 079 & 079 \\
\hline & 2 & & & & 0.50 & 0.25 & 0.50 & 0.88 & 2.40 & 1.39 & 1.20 & 0.76 & 0.38 & 1.45 & 1.00 & & 0.19 \\
\hline 7-B-11 & 1 & 9 & 0.98 & -0 & 1.51 & 1.58 & 0.38 & 0.50 & 0.50 & 0.44 & 2.02 & 0.88 & 0.50 & 0.82 & 117 & 062 & $0 \leq$ \\
\hline $2-\mathrm{D}-11$ & 2 & 9 & 0.90 & -0.503 & 1.14 & 2.14 & 2.14 & 1.39 & 2.08 & 0.95 & 1.77 & 1.20 & 0.76 & 0.76 & 1.17 & 0.02 & 0.53 \\
\hline 7 & 1 & 16 & 1 & & 0.88 & 1.96 & 3.34 & 1.07 & 1.04 & 1.26 & 1.07 & 1.20 & 1.96 & 0.88 & & & \\
\hline $2-D-12$ & 2 & 10 & 1.00 & -0.580 & 5.52 & 0.47 & 1.70 & 0.38 & 4.48 & 0.44 & 6.31 & $8.71^{\ddagger}$ & 0.38 & 0.57 & 1.84 & 1.78 & 0.97 \\
\hline & & & & & & & & & & & & & & erage & 2.57 & & \\
\hline
\end{tabular}

${ }^{*} \mathrm{Z}=$ galvanized steel and $\mathrm{B}=$ beam specimens.

${ }^{\dagger}$ Ten chloride samples taken from each side of bar per specimen.

‡Outlier sample.

Note: $1 \mathrm{lb} / \mathrm{yd}^{3}=0.5933 \mathrm{~kg} / \mathrm{m}^{3}$ 
Table 3-Conventional (ASTM A615) steel critical chloride threshold

\begin{tabular}{|c|c|c|c|c|c|c|c|c|c|c|c|c|c|c|c|c|c|}
\hline \multirow[b]{2}{*}{ Specimens* } & \multirow[b]{2}{*}{ Bar } & \multirow{2}{*}{$\begin{array}{l}\text { Age, } \\
\text { weeks }\end{array}$} & \multirow{2}{*}{$\begin{array}{c}\text { Rate, } \\
\mu \mathrm{m} / \text { year }\end{array}$} & \multirow{2}{*}{$\begin{array}{c}\text { Potential, } \\
\mathrm{V}\end{array}$} & \multicolumn{10}{|c|}{ Water soluble $\mathrm{Cl}^{-}, \mathrm{lb} / \mathrm{yd}^{3}$} & \multirow{2}{*}{$\begin{array}{c}\text { Average, } \\
\mathrm{lb} / \mathrm{yd}^{3}\end{array}$} & \multirow{2}{*}{$\begin{array}{l}\text { Standard } \\
\text { deviation }\end{array}$} & \multirow{2}{*}{$\begin{array}{l}\text { Coefficient } \\
\text { of variation }\end{array}$} \\
\hline & & & & & 1 & 2 & 3 & 4 & 5 & 6 & 7 & 8 & 9 & 10 & & & \\
\hline \multirow{2}{*}{ C-MSE-1 } & $1^{\dagger}$ & - & - & - & - & - & - & - & - & - & - & - & - & - & \multirow{2}{*}{1.56} & \multirow{2}{*}{0.74} & \multirow{2}{*}{0.48} \\
\hline & 2 & 8 & 0.84 & -0.273 & 0.69 & 1.51 & 1.68 & 2.71 & 1.20 & - & - & - & - & - & & & \\
\hline \multirow{2}{*}{ C-MSE-2 } & $1^{\dagger}$ & - & - & - & - & - & - & - & - & - & - & - & - & - & \multirow{2}{*}{1.56} & \multirow{2}{*}{0.62} & \multirow{2}{*}{0.40} \\
\hline & 2 & 12 & 2.89 & -0.396 & 0.94 & 2.39 & 1.28 & $4.78^{\ddagger}$ & 1.64 & - & - & - & - & - & & & \\
\hline \multirow{2}{*}{ C-MSE-3 } & 1 & 15 & 1.96 & -0.404 & 0.69 & 0.82 & 0.63 & 0.82 & 0.94 & 1.83 & 1.26 & 2.58 & - & - & \multirow{2}{*}{1.32} & \multirow{2}{*}{0.64} & \multirow{2}{*}{0.48} \\
\hline & 2 & 14 & 1.79 & -0.380 & $3.65^{\ddagger}$ & 1.70 & 1.01 & 1.32 & 2.27 & - & - & - & - & - & & & \\
\hline \multirow{2}{*}{ C-MSE-4 } & 1 & 9 & 1.76 & -0.379 & 0.77 & 1.03 & 0.85 & 0.86 & 0.77 & 0.77 & 0.58 & 1.29 & 0.77 & 1.37 & \multirow{2}{*}{0.98} & \multirow{2}{*}{0.32} & \multirow{2}{*}{0.33} \\
\hline & 2 & 9 & 3.51 & -0.421 & 0.80 & 1.04 & 1.67 & 0.60 & 0.77 & 1.02 & 0.84 & 1.38 & 0.77 & 1.63 & & & \\
\hline \multirow{2}{*}{ C-MSE-5 } & 1 & 14 & 0.82 & -0.332 & 1.70 & 2.33 & 2.39 & 1.64 & 1.83 & 1.13 & 1.51 & 0.92 & 0.73 & 1.20 & \multirow{2}{*}{1.22} & \multirow{2}{*}{0.54} & \multirow{2}{*}{0.44} \\
\hline & 2 & 9 & 0.35 & -0.280 & 0.87 & 0.84 & 0.65 & 1.03 & 0.69 & 0.87 & 0.73 & 0.73 & 1.60 & 0.94 & & & \\
\hline С МСГ & 1 & 20 & 1.52 & -0.361 & 1.51 & 1.38 & 1.83 & 2.64 & 3.21 & 1.33 & 3.02 & 1.45 & 2.27 & 2.08 & P0 & 060 & 020 \\
\hline C-MSSE-O & 2 & 17 & 1.84 & -0.379 & 2.71 & 1.83 & 1.83 & 3.02 & 2.83 & 1.13 & 1.16 & 1.32 & 2.20 & 1.70 & 2.02 & 0.68 & 0.34 \\
\hline & $\mathrm{Side}^{\S}$ & & & & & & & & & & & & & & & & \\
\hline & 1 & & & & 1.51 & 2.46 & 1.26 & 2.27 & 1.38 & 3.08 & 1.89 & 1.64 & 1.95 & 1.57 & & & \\
\hline C-B-1 & 2 & 21 & 1.17 & -0.358 & $4.36^{\ddagger}$ & 2.29 & 1.95 & 2.31 & 1.45 & 3.02 & 0.95 & 1.40 & 2.20 & 1.21 & 1.88 & 0.59 & 0.32 \\
\hline & 1 & & & & 2.27 & 0.85 & 1.82 & 1.67 & 1.30 & 1.36 & 1.48 & 1.54 & 1.36 & 1.54 & & & \\
\hline$C-B-2$ & 2 & 23 & 1.17 & -0.392 & 1.13 & 2.71 & 2.71 & 2.77 & 2.58 & 2.84 & 2.33 & 1.55 & 2.96 & $4.81^{*}$ & 1.94 & 0.67 & 0.35 \\
\hline$C \mathrm{D} 3$ & 1 & 14 & 102 & 034 & 2.27 & 1.04 & 1.89 & 2.77 & $3.97^{\ddagger}$ & 2.51 & 1.13 & 1.89 & 2.52 & 1.51 & 107 & 066 & 023 \\
\hline & 2 & & & & 2.14 & 3.08 & 1.57 & 2.90 & 2.20 & 0.82 & 1.20 & 2.58 & 1.89 & 1.57 & & & \\
\hline & & & & & & & & & & & & & & iverage & 1.63 & & \\
\hline
\end{tabular}

${ }^{*} \mathrm{C}=$ conventional steel $; \mathrm{B}=$ beam specimens; $\mathrm{MSE}=$ modified southern exposure.

†Sample not available.

${ }^{\ddagger}$ Outlier sample.

${ }^{\S}$ Ten chloride samples taken from each side of bar per specimen.

Note: $1 \mathrm{lb} / \mathrm{yd}^{3}=0.5933 \mathrm{~kg} / \mathrm{m}^{3}$.

Table 4-ASTM A1035 steel critical chloride threshold

\begin{tabular}{|c|c|c|c|c|c|c|c|c|c|c|c|c|c|c|c|c|c|}
\hline \multirow[b]{2}{*}{ Specimens* } & \multirow[b]{2}{*}{ Bar } & \multirow{2}{*}{$\begin{array}{l}\text { Age, } \\
\text { weeks }\end{array}$} & \multirow{2}{*}{$\begin{array}{l}\text { Rate, } \\
\mu \mathrm{m} / \text { year }\end{array}$} & \multirow{2}{*}{$\begin{array}{c}\text { Potential, } \\
\text { V }\end{array}$} & \multicolumn{10}{|c|}{ Water soluble $\mathrm{Cl}^{-}, \mathrm{lb} / \mathrm{yd}^{3}$} & \multirow{2}{*}{$\begin{array}{c}\text { Average, } \\
1 \mathrm{~b} / \mathrm{yd}^{3}\end{array}$} & \multirow{2}{*}{$\begin{array}{l}\text { Standard } \\
\text { deviation }\end{array}$} & \multirow{2}{*}{$\begin{array}{l}\text { Coefficient } \\
\text { of variation }\end{array}$} \\
\hline & & & & & 1 & 2 & 3 & 4 & 5 & 6 & 7 & 8 & 9 & 10 & & & \\
\hline \multirow{2}{*}{ M-MSE-1 } & 1 & 23 & 0.50 & -0.390 & 5.41 & 5.98 & 5.70 & 7.93 & 9.82 & 10.3 & 11.08 & $11.5^{\ddagger}$ & 10.6 & $11.8^{\ddagger}$ & \multirow{2}{*}{6.53} & \multirow{2}{*}{2.59} & \multirow{2}{*}{0.40} \\
\hline & 2 & 17 & 0.60 & -0.362 & 2.64 & 2.96 & 3.90 & 3.71 & 4.66 & 7.37 & 6.17 & 6.55 & 7.24 & 5.60 & & & \\
\hline \multirow{2}{*}{ M-MSE-2 } & 1 & 23 & 0.41 & -0.333 & 5.85 & 4.85 & 10.1 & 8.99 & 10.7 & - & - & - & - & - & \multirow{2}{*}{8.49} & \multirow{2}{*}{1.59} & \multirow{2}{*}{0.19} \\
\hline & 2 & 28 & 0.01 & -0.363 & 7.43 & 8.75 & 9.38 & 9.13 & 10.1 & 8.75 & $13.1^{\ddagger}$ & 8.37 & 8.25 & 8.37 & & & \\
\hline \multirow{2}{*}{ M-MSE-3 } & $1^{\dagger}$ & - & - & - & - & - & - & - & - & - & - & - & - & - & \multirow{2}{*}{5.45} & \multirow{2}{*}{1.66} & \multirow{2}{*}{0.30} \\
\hline & 2 & 17 & 1.95 & -0.460 & 2.52 & 4.09 & 4.31 & 5.04 & 5.73 & 7.55 & 6.23 & 8.18 & 5.04 & 5.79 & & & \\
\hline \multirow{2}{*}{ M-MSE-4 } & 1 & 30 & 0.57 & -0.348 & 3.15 & 5.10 & 5.29 & 6.30 & 5.67 & 5.67 & 3.84 & - & - & - & \multirow{2}{*}{4.69} & \multirow{2}{*}{1.37} & \multirow{2}{*}{0.29} \\
\hline & 2 & 29 & 2.00 & -0.367 & 4.91 & 3.97 & 3.46 & 6.67 & 5.10 & 2.14 & 2.64 & 6.48 & 5.60 & 3.78 & & & \\
\hline M-MSE- $5^{\S}$ & - & - & - & - & - & - & - & - & - & - & - & - & - & - & - & - & - \\
\hline \multirow{3}{*}{ M-MSE-6 } & 1 & 26 & 1.20 & -0.359 & 5.04 & 2.71 & 3.53 & 4.28 & 4.28 & 7.21 & \begin{tabular}{|l|}
3.78 \\
\end{tabular} & 4.60 & 6.11 & 4.85 & \multirow{2}{*}{6.99} & \multirow{2}{*}{2.11} & \multirow{2}{*}{0.30} \\
\hline & 2 & 39 & 0.68 & -0.368 & 4.23 & 4.91 & 5.59 & 5.36 & 5.21 & 5.67 & 6.80 & 5.89 & 3.10 & 5.59 & & & \\
\hline & Side & & & & & & & & & & & & & & & & \\
\hline \multirow{2}{*}{ M-B-1 } & 1 & 51 & 102 & $=36$ & 7.30 & 9.25 & 9.63 & 8.61 & 9.32 & 10.4 & \begin{tabular}{|l|}
10.39 \\
\end{tabular} & 7.22 & 7.30 & 8.12 & 656 & 310 & 047 \\
\hline & 2 & & & & 9.95 & 9.90 & 10.5 & 10.1 & 8.08 & 9.95 & 9.63 & 8.31 & 10.3 & 6.48 & 0.56 & 3.10 & 0.47 \\
\hline M-B-2 & 1 & 26 & 122 & - 344 & 2.14 & 2.46 & 3.15 & 3.12 & 5.29 & 2.71 & \begin{tabular}{|l|}
3.78 \\
\end{tabular} & 4.09 & 5.92 & 5.29 & 654 & 169 & 026 \\
\hline & 2 & & & & 3.84 & 4.78 & 5.67 & 5.54 & 5.16 & 5.73 & 7.62 & 9.38 & 7.49 & 6.56 & 0.54 & & 0.20 \\
\hline 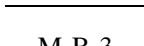 & 1 & 36 & 0.56 & ( & 6.42 & 6.30 & 6.78 & 8.03 & 7.35 & 5.23 & 5.23 & 7.81 & 10.9 & 4.97 & 6027 & 172 & קר \\
\hline MI-B-3 & 2 & 30 & 0.50 & -0.329 & 8.37 & 6.17 & 4.60 & 5.92 & 5.35 & 8.00 & 8.31 & 2.91 & 6.54 & 6.06 & 0.22 & 1.12 & 0.28 \\
\hline
\end{tabular}

${ }^{*} \mathrm{M}=$ ASTM A1035 steel; $\mathrm{B}=$ beam specimens; MSE $=$ modified southern exposure.

†Sample not available.

†Outlier sample.

${ }^{\S}$ Specimen contaminated from exterior, sample not used.

"Ten chloride samples taken from each side of bar per specimen.

Note: $1 \mathrm{lb} / \mathrm{yd}^{3}=0.5933 \mathrm{~kg} / \mathrm{m}^{3}$. 
exposure specimens (similar to the MSE specimens, but with an electrical connection between the two top bars) containing 316LN clad bars at 96 weeks.

The conventional steel bars had times-to-initiation ranging from 8 to 23 weeks, with an average corrosion rate of $1.50 \mu \mathrm{m} /$ year and an average corrosion potential of $-0.362 \mathrm{~V}$ with respect to a copper-copper sulfate electrode at corrosion initiation. After the removal of outliers, the average chloride threshold is $1.63 \mathrm{lb} / \mathrm{yd}^{3}\left(0.97 \mathrm{~kg} / \mathrm{m}^{3}\right)$. The individual chloride contents range from 0.58 to $3.21 \mathrm{lb} / \mathrm{yd}^{3}(0.34$ to $\left.1.90 \mathrm{~kg} / \mathrm{m}^{3}\right)$, and the average values for the individual specimens range from 0.98 to $2.02 \mathrm{lb} / \mathrm{yd}^{3}\left(0.58\right.$ to $\left.1.20 \mathrm{~kg} / \mathrm{m}^{3}\right)$. The COV for individual bars ranges from 0.32 to 0.48 , and the $\mathrm{COV}$ for the average specimen threshold values is 0.38 .

The ASTM A1035 bars had times-to-initiation ranging from 17 to 51 weeks, with an average corrosion rate of $0.902 \mu \mathrm{m} /$ year and an average corrosion potential of $-0.361 \mathrm{~V}$ with respect to a copper-copper sulfate electrode at corrosion initiation. After the removal of outliers, the average chloride threshold is $6.34 \mathrm{lb} / \mathrm{yd}^{3}\left(3.76 \mathrm{~kg} / \mathrm{m}^{3}\right)$. The individual chloride contents range from 2.14 to $11.08 \mathrm{lb} / \mathrm{yd}^{3}\left(1.27\right.$ to $\left.6.57 \mathrm{~kg} / \mathrm{m}^{3}\right)$, and the average values for the individual specimens range from 4.69 to $8.49 \mathrm{lb} / \mathrm{yd}^{3}\left(2.78\right.$ to $\left.5.04 \mathrm{~kg} / \mathrm{m}^{3}\right)$. The COV for individual bars ranges from 0.19 to 0.47 , and the COV for the average specimen threshold values is 0.31 .

The individual southern exposure specimens containing the 316LN clad bars had average chloride contents at 96 weeks ranging from 14.83 to $24.02 \mathrm{lb} / \mathrm{yd}^{3}$ (8.80 to $14.25 \mathrm{~kg} / \mathrm{m}^{3}$ ), with an average for all specimens value of $19.14 \mathrm{lb} / \mathrm{yd}^{3}$ $\left(11.36 \mathrm{~kg} / \mathrm{m}^{3}\right)$.

Tables 2 though 4 demonstrate that, with an average value of $2.57 \mathrm{lb} / \mathrm{yd}^{3}\left(1.52 \mathrm{~kg} / \mathrm{m}^{3}\right)$, galvanized steel has a higher critical corrosion threshold than conventional reinforcing steel (average value of $1.63 \mathrm{lb} / \mathrm{yd}^{3}\left[0.97 \mathrm{~kg} / \mathrm{m}^{3}\right]$ ) and a lower threshold than ASTM A1035 steel (average value of $6.34 \mathrm{lb} / \mathrm{yd}^{3}$ $\left.\left[3.76 \mathrm{~kg} / \mathrm{m}^{3}\right]\right)$, as well as a lower threshold than $316 \mathrm{LN}$ steel. The tables also demonstrate that the corrosion threshold is not a single value for a metal, but rather a range of values. This point is illustrated in Fig. 4, which shows the ranges of chloride sample values at corrosion initiation for galvanized, conventional, and ASTM A1035 reinforcement. The galvanized and ASTM A1035 bars exhibit wider ranges than conventional steel. On the low side, galvanized steel exhibits low average values of the chloride threshold for individual specimens that match those exhibited by conventional steel. For example, the three lowest values of the critical chloride corrosion threshold for individual galvanized bar specimens range from 1.00 to $1.07 \mathrm{lb} / \mathrm{yd}^{3}$ (0.59 to $\left.0.63 \mathrm{~kg} / \mathrm{m}^{3}\right)$, which are similar to the three lowest values for conventional steel, which range from 0.98 to $1.32 \mathrm{lb} / \mathrm{yd}^{3}\left(0.58\right.$ to $\left.0.78 \mathrm{~kg} / \mathrm{m}^{3}\right)$ (Tables 2 and 3). In contrast, on the high side, the three highest values of the critical chloride corrosion threshold for galvanized bars range from 3.88 to $4.93 \mathrm{lb} / \mathrm{yd}^{3}(2.30$ to $2.92 \mathrm{~kg} / \mathrm{m}^{3}$ ), which are far greater than the three highest values for conventional steel, which range from 1.94 to $2.02 \mathrm{lb} /$ $\mathrm{yd}^{3}\left(1.15\right.$ to $\left.1.20 \mathrm{~kg} / \mathrm{m}^{3}\right)$. This wide range in critical chloride values may help explain the widely varying level of performance reported for galvanized reinforcement in concrete. The lowest three and highest three values for ASTM A1035 steel, respectively, range from 4.69 to $6.22 \mathrm{lb} / \mathrm{yd}^{3}\left(2.78\right.$ to $\left.3.69 \mathrm{~kg} / \mathrm{m}^{3}\right)$ and 6.56 to $8.49 \mathrm{lb} / \mathrm{yd}^{3}$ (3.89 to $5.01 \mathrm{~kg} / \mathrm{m}^{3}$ ) (Table 4).

The results in Tables 2 through 4 can be used to estimate the time to corrosion initiation for the three types of steel. This can be done in conjunction with chloride surveys reported by Miller and Darwin (2000) and Lindquist et al. (2005, 2006) for bridge decks. Figure 5 shows the chloride values at a nominal depth of $3 \mathrm{in.}(76 \mathrm{~mm}$ ) (interpolated from samples taken at $2-1 / 4$ to $3 \mathrm{in}$. [57 to $76 \mathrm{~mm}$ ] and 3 to $3-3 / 4$ in. [76 to $95 \mathrm{~mm}$ ]) at crack locations. These values are chosen because 3 in. ( $76 \mathrm{~mm}$ ) is the upper value of cover typically used in bridge decks, and cracks generally form directly over the top bars in the deck (Miller and Darwin 2000; Lindquist et al. 2005, 2006).

Using the average values for the corrosion thresholds and the best fit line of chloride content versus time shown in Fig. 5, the average times to corrosion initiation for conventional, galvanized, and ASTM A1035 steel at cracks in concrete bridge decks are 2.3 years, 4.8 years, and 15 years, respectively. Thus, using galvanized steel should extend the time to corrosion initiation by an average of just 2.5 years over the time for unprotected conventional steel. ASTM A1035 steel should extend the time by an average of 12.5 years. All three systems will exhibit significantly longer times to corrosion initiation in uncracked concrete (Lindquist et al. 2006). A comparison using the average chloride content of $19.14 \mathrm{lb} / \mathrm{yd}^{3}\left(11.36 \mathrm{~kg} / \mathrm{m}^{3}\right)$ for the $316 \mathrm{LN}$ clad bars indicates that it would take nearly 50 years to reach this lower bound value, a value that in itself is not associated with corrosion of $316 \mathrm{LN}$ steel.

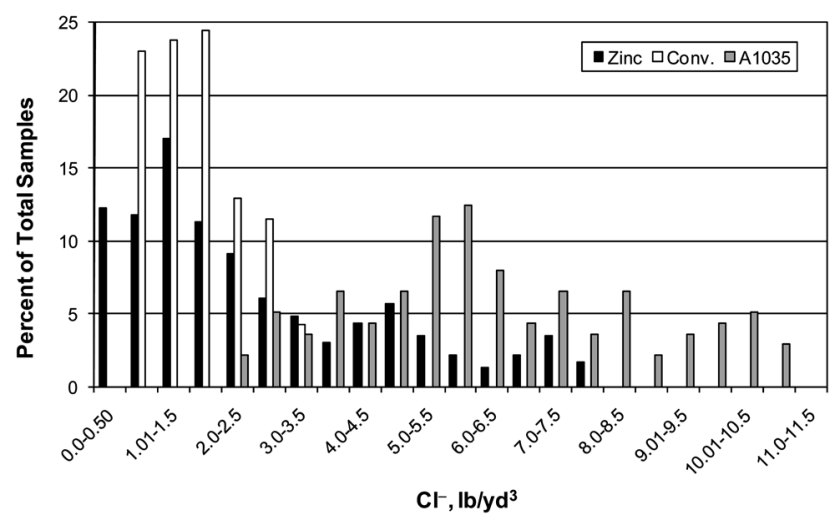

Fig. 4-Comparison of ranges of chloride sample values at corrosion initiation for galvanized (Zinc), conventional (Conv.), and low carbon chromium (ASTM A1035) reinforcement. (Note: $1 \mathrm{lb} / \mathrm{yd}^{3}=0.5933 \mathrm{~kg} / \mathrm{m}^{3}$.)

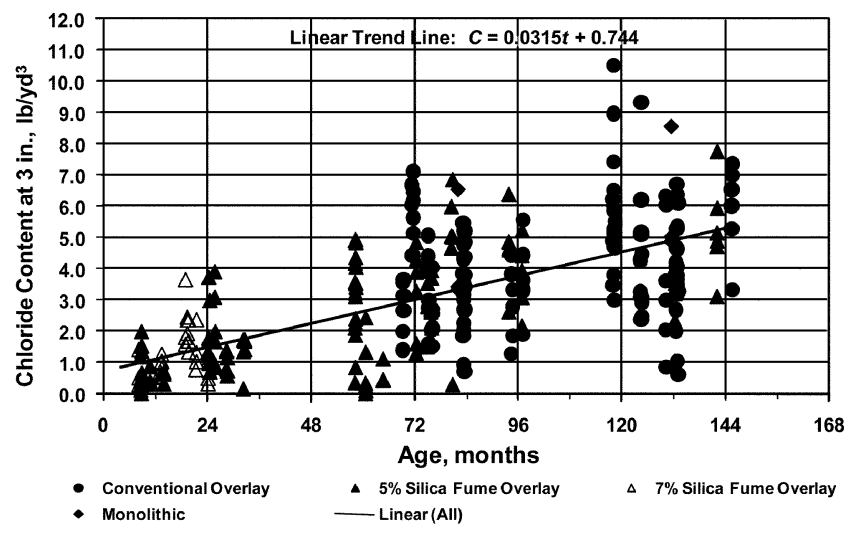

Fig. 5-Chloride content taken on cracks interpolated at depth of 3 in. (76 mm) versus placement age for bridges with annual average daily traffic (AADT) greater than 7500 (Lindquist et al. 2005, 2006). (Note: $1 \mathrm{lb} / \mathrm{yd}^{3}=0.5933 \mathrm{~kg} / \mathrm{m}^{3}$.) 


\section{Autopsy results}

Following the tests, the specimens were examined to determine the degree of corrosion of the reinforcing bars and for signs of increased porosity due to hydrogen formation. For all 12 galvanized steel test specimens, a white crystalline corrosion product was visible on portions of the top bars. An example is shown in Fig. 6. The crystals are large (dimensions of 10 to 30 mils [ 0.25 to $0.75 \mathrm{~mm}$ ]), indicating that the $\mathrm{pH}$ of the concrete was above 13.3 (Andrade and Macias 1988; Bentur et. al. 1997) and that these regions of zinc had not been passivated. Seven of the 12 specimens had sufficient local corrosion losses on the top bar to result in the loss of a portion of the outer pure zinc layer, exposing the outer zinciron intermetallic layer, which appears as a black area centered in the white zinc corrosion product (Fig. 7). No correlation was observed between the corrosion threshold and the loss of the outer zinc layer. Three of 12 specimens exhibited bottom-bar corrosion in addition to the top-bar corrosion.

Measurements of the total coating thickness of uncorroded zinc using a pulloff gauge produced values ranging from 6.8 to 10 mils $(0.17$ to $0.25 \mathrm{~mm}$ ), with an average of $7.6 \mathrm{mils}$ $(0.19 \mathrm{~mm})$ and a standard deviation of 0.96 mils $(0.024 \mathrm{~mm})$. Measurements of the coating thickness at corrosion sites ranged from 6.25 to 8.5 mils ( 0.16 to $0.22 \mathrm{~mm}$ ), with an average of 7.31 mils $(0.19 \mathrm{~mm})$ and a standard deviation of 0.93 mils $(0.024 \mathrm{~mm})$. Comparing the average thicknesses of the corroded and uncorroded areas on individual specimens shows at most a 2 mil $(0.05 \mathrm{~mm})$ loss in regions where the pure zinc layer had been lost (this occurred on a bar with a coating thickness of 10 mils $[0.25 \mathrm{~mm}])$. Thus, at the time of the autopsy, it appears that only the pure layer of zinc had been lost. This loss, however, does not bode well for the long-term performance of the bars-without the outer layer of pure zinc, the intermetallic layers are subject to corrosion because the protective layer of calcium hydroxyzincate cannot form (Andrade and Macias 1988).

During the autopsy, the concrete was also examined for signs of increased porosity due to hydrogen formation. For all specimens, the concrete below the bar exhibited increased porosity relative to the concrete above the bar.

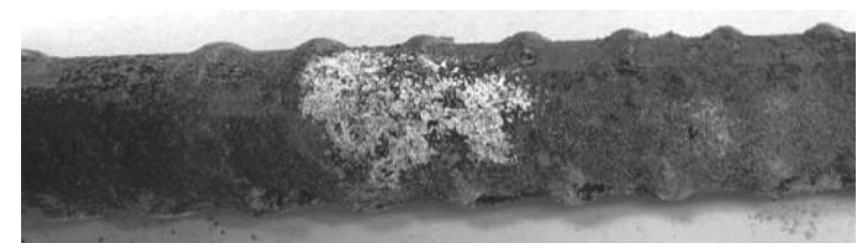

Fig. 6-Bar from Specimen Z-B-8 after autopsy. Corrosion product on top bar. Nominal bar diameter $=5 / 8$ in. $(16 \mathrm{~mm})$.

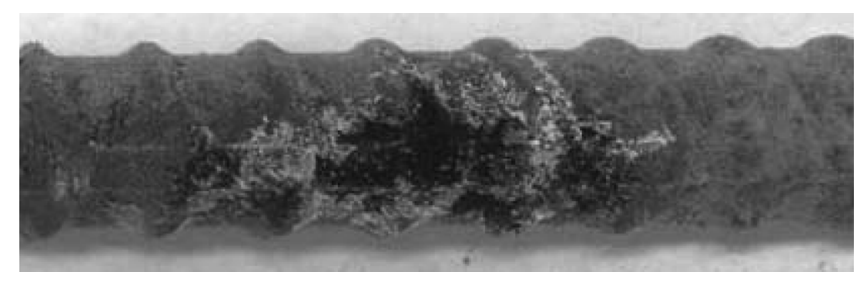

Fig. 7-Bar from Specimen Z-B-3 after autopsy. Corrosion product on top bar showing intermetallic layer. Nominal bar diameter $=5 / 8$ in. $(16 \mathrm{~mm})$.
This effect, however, was likely due to the entrained air rather than hydrogen formation, as increased porosity under the bar was also noted in concrete cast with conventional steel reinforcement. Thus, the increase in local porosity observed in the zinc-coated specimens appears to be comparable with that observed in specimens containing conventional steel reinforcement.

\section{SUMMARY OF FINDINGS}

The beam tests demonstrate that galvanized reinforcement increases the time to corrosion initiation compared with conventional steel. The average critical corrosion threshold for galvanized reinforcement, $2.57 \mathrm{lb} / \mathrm{yd}^{3}\left(1.5 \mathrm{~kg} / \mathrm{m}^{3}\right)$, is higher than the observed critical corrosion threshold of conventional (A615) steel, $1.63 \mathrm{lb} / \mathrm{yd}^{3}\left(0.97 \mathrm{~kg} / \mathrm{m}^{3}\right)$, and lower than the value for A1035 steel, $6.34 \mathrm{lb} / \mathrm{yd}^{3}\left(3.76 \mathrm{~kg} / \mathrm{m}^{3}\right)$, and the lower-bound value for $316 \mathrm{LN}$ stainless steel, $19.14 \mathrm{lb} / \mathrm{yd}^{3}$ $\left(11.36 \mathrm{~kg} / \mathrm{m}^{3}\right)$. The coefficient of variation for zinc reinforcement is larger than that for conventional and A1035 reinforcement, potentially indicating a greater variation in the performance of galvanized reinforcement. Zinc corrosion products were observed on the top bar for all 12 specimens. Increased porosity was noted in the concrete directly beneath the reinforcement, but the increase is comparable with that caused by entrained air for specimens containing conventional reinforcement.

\section{CONCLUSIONS}

The following conclusions are based on the results and analyses presented in this paper:

1. Galvanized reinforcement has a higher average critical chloride corrosion threshold than conventional (ASTM A615) steel and a lower threshold than low carbon chromium (ASTM A1035) reinforcement or 316LN stainless steel;

2. The range of values of chloride content at corrosion initiation is greater for galvanized reinforcement than for conventional reinforcement. On the low side, galvanized steel exhibited values that are similar in magnitude to those exhibited by conventional steel. This may explain some of the variation in performance observed in the field for galvanized reinforcing steel;

3. Some zinc corrosion products were observed on the surface of the galvanized bars;

4. Concrete adjacent to the non-chromate treated bars evaluated in this study revealed no evidence of an increase in porosity due to hydrogen gas evolution during curing when compared to conventional reinforcement in similar airentrained concrete. The galvanized bars, however, showed signs of corrosion, including exposure of the intermetallic layer on some. The loss of the zinc layer may be due to the lack of chromate treatment or due to loss of metal in the presence of high-pH concrete pore solution;

5. Based on chloride surveys of cracked bridge decks, galvanized steel can be expected to increase the average time to corrosion initiation at crack locations from 2.3 years for conventional steel to 4.8 years for bars with 3 in. $(76 \mathrm{~mm})$ of concrete cover. Corrosion initiation would be expected to occur at an average age of 15 years for ASTM A1035 reinforcement and not to occur for bars consisting of $316 \mathrm{LN}$ stainless steel.

\section{ACKNOWLEDGMENTS}

Funding and material support for this research was provided by the International Lead Zinc Research Organization, Inc. under Project Code ZC-24-2 and the South Dakota Department of Transportation under Project 
SD2002-16, with technical oversight by D. Johnston. Additional support was provided by the Kansas Department of Transportation under Contract No. C1281, with technical oversight by D. Whisler, MMFX Technologies Corporation, the Ash Grove Cement Company, BASF Construction Chemicals, and LRM Industries.

\section{REFERENCES}

Andrade, M. C., and Macias, A., 1988, "Galvanized Reinforcements in Concrete," Surface Coatings-2, A. D. Wilson, J. W. Nicolson, and H. J. Prosser, eds., Elsevier Applied Science, London, UK, pp. 137-182.

AASHTO T 260, 1997, "Standard Method of Test for Sampling and Testing for Chloride Ion in Concrete and Concrete Raw Materials," AASHTO, Washington, DC.

ASTM A615/A615M, 2007, "Standard Specification for Deformed and Plain Carbon-Steel Bars for Concrete Reinforcement," ASTM International,

West Conshohocken, PA, 5 pp.

ASTM A767/A767M, 2005, "Standard Specification for Zinc-Coated (Galvanized) Steel Bars for Concrete Reinforcement," ASTM International,

West Conshohocken, PA, 4 pp.

ASTM A1035/A1035M, 2007, "Standard Specification for Deformed and Plain, Low-Carbon, Chromium, Steel Bars for Concrete Reinforcement," ASTM International, West Conshohocken, PA, 5 pp.

ASTM G109, 2007, "Standard Test Method for Determining Effects of Chemical Admixtures on Corrosion of Embedded Steel Reinforcement in Concrete Exposed to Chloride Environments," ASTM International, West Conshohocken, PA, 6 pp.

Bentur, A.; Diamond, S.; and Berke, N. S., 1997, Steel Corrosion in Concrete, E\&FN Spon, New York, 133 pp.

Darwin, D.; Browning, J.; Nguyen, T. V.; and Locke, C. E., 2007a, "Evaluation of Metallized Stainless Steel Clad Reinforcement," South Dakota Department of Transportation Report, SD2001-05-F, July, 156 pp.

Darwin, D.; Browning, J. P.; O’Reilly, M.; and Xing, L., 2007b, “Critical Chloride Corrosion Threshold for Galvanized Reinforcing Bars," SL
Report 07-2, University of Kansas, Center for Research, Lawrence, KS, Dec., 28 pp.

Ji, J.; Darwin, D.; and Browning, J., 2005, "Corrosion Resistance of Duplex Stainless Steels and MMFX Microcomposite Steel for Reinforced Concrete Bridge Decks," SM Report No. 80, University of Kansas Center for Research, Lawrence, KS, Dec., 453 pp.

Jones, D. A., 1996, Principles and Prevention of Corrosion, Macmillan Publishing Co., New York, 500 pp.

Lindquist, W. D.; Darwin, D.; and Browning, J. P., 2005, "Cracking and Chloride Contents in Reinforced Concrete Bridge Decks," SM Report No. 78, University of Kansas Center for Research, Lawrence, KS, Feb., $453 \mathrm{pp}$.

Lindquist, W. D.; Darwin, D.; Browning, J.; and Miller, G. G., 2006, "Effect of Cracking on Chloride Content in Concrete Bridge Decks," ACI Materials Journal, V. 103, No. 6, Nov.-Dec., pp. 467-473.

Manning, D. G.; Escalante, E.; and Whiting, D., 1982, "Panel ReportGalvanized Rebars as Long-Term Protective System," Washington, DC.

McCrum, L., and Arnold, C. J., 1993, "Evaluation of Simulated Bridge Deck Slabs Using Uncoated, Galvanized, and Epoxy Coated Reinforcing Steel," Research Report No. R-1320, Michigan Department of Transportation, Lansing, MI.

Miller, G., and Darwin, D., 2000, "Performance and Constructability of Silica Fume Bridge Deck Overlays," SM Report No. 57, The University of Kansas Center for Research, Lawrence, KS, 423 pp.

NIOSH, 2005, http://www.cdc.gov/niosh/npg/npgd0138.html.

Pianca, F., and Schell, H., 2005, "The Long Term Performance of Three Ontario Bridges Constructed with Galvanized Reinforcement," Report, Ontario Ministry of Transportation, Downsview, ON, Canada, 30 pp.

Struble, L., 1988, "The Influence of Cement Pore Solution on AlkaliSilica Reaction," National Bureau of Standards NBSIR 87-3632.

Virmani, Y. P., and Clemeña, G. G., 1998, "Corrosion Protection Concrete Bridges," Report No. FHWA-RD-98-099, Federal Highway Administration, Washington, DC. 